the Dark Argus in Mr. Humphrey's book ; so would you kindly inform me whether this is a new locality, and whether there are two broods, the first in May and the second in July, as is the case with several of family, as would appear from the above statements? I identify the species with his Dark Argus by the following peculiarities, viz. : (I) an obscure black spot near centre of fore-wings; (2) no black spots in the orange ocelli in forewings, the hind-wings containing these black spots as in the Brown Argus.

West Derby, near Lirerpool

\section{Meteorological Phenomenon}

WHILE walking out yesterday afternoon my attention was drawn to a very remarkable display of mares-tail clouds spread. ing from the north, stretching in broad and narrow bands in every direction over the whole sky, and reaching beyond the zenith. While standing thus facing the sun, I saw, at a great elevation, a coloured bow with its convex red side towards the sun; it was only about one-sixth or one-seventh of a circle, and its width seemed to be only about half that of an average ordinary rain. bow. It had the appearance of being nearly horizontal, with its centre not far from the zenith, but probably not so distant. Not being accustomed to estimate elevations, when I got home I touk a quadrant and held it about the elevation of the part of the bow nearest the sun, and found it came out, on repeated trials, at a zerrit/s distance of $25^{\circ}$ or $26^{\circ}$.* When I first saw the bow it was just $6 \mathrm{~h} .3 \mathrm{Om}$. P.M. Greenwich time, and the sun appeared to be about $\mathbf{I} 5^{\circ}$ above the horizon (that you can correct by calculation). The sun was shining brightly, and the bow was projected over a patch of sky slightly dimmed, at a great height (but below the cirri?), by a smoke-grey haze; its ends just projected over the edges of the clonds. It lasted about $2 \mathrm{~m}$. and then faded away. There was no halo or ring but this. The wind was a rather fresh breeze, between S.S.E. and S.

Norwich, June 28

HIENRY NORTON

\section{OUR ASTRONOMTCAL COLUMN}

SUFI'S DESCRIPTION OF THE FIXED STARS.-The author of the ancient Uranometria to which we adverted last week, Abd-al-Rahman al-Sûfi (an abbreviation of a much longer name), was born in 903; he was of the sect of the Sûfis, and of Rai, a place to the east of Teheran. He was in high favour with Adhad a1-Davlat, of the reigning family of Persia, and it was principally for the instruction of this prince that he wrote the work under notice, which was not the only one he produced. Ibn Jounis reports that he was not only an observer, but framed astronomical tables; and Dr. Schjellerup states he is known to have undertaken geodetic operations. He is said to have determined the length of the year, and in his tables fixes the mean motion of the sun in the Persian year at $359^{\circ} 45^{\prime} 40^{\prime \prime} \%$. He died in May 986 . The prince Adhad al-Davlat, who gave great encouragement to the study of the sciences, commenced his reign in 949 , and at the time of his death, in 983 , governed the extent of country situate between the Caspian and the Persian Guif.

The translation of the "Description of the Fixed Stars" by Sîfi was made by Dr. Schjellerup from a manuscript preserved in the Royal Library at Copenhagen, which came into the possession of Niebuhr in 1763 . It is a copy made in 160 I from a manuscript transcribed in Ior 3 , and, as stated by Schjellerup, "directement d'après l'exemplaire de Sûfif." The translation was finished when the Danish astronomer, through Herr Dorn, had the opportunity of consulting another copy of Sûfi's work, recently acquired by the Imperial Library of St. Petersburg. Where differences exist between the two authorities, they are particularised in notes to Schjellerup's translation.

The description of the stars by Suf, though founded upon that of Ptolemy, is not merely a simple translation. All the stars contained in Ptolemy's catalogue were sought in the positions there recorded, and submitted to attentive examination, and their magnitudes carefully * Subtended at my eye by bow and sun $=$ about $50^{\circ}$ ? noted, as is distinctly stated by Sûf in his preface. Schjellerup draws attention to the great extent of his work, the perseverance displayed, and the minute accuracy and scientific criticism with which the whole is executed; so that, wnder all circumstances, the Persian astronomer has presented us with the state of the sidereal heavens in his time, which merits the highest confidence, and which during nine centuries remains without a rival, not having found its equal till the appearance of the "Uranometria Nova" of Argelander.

Prefixed to the description of the constellations, Schjellerup has published what he terms "Tableau synoptique de lintensité lumineuse des étoiles principales selon Ptolemée (ou Hipparch), Sûfi et Argelander," which is obviously a valuable compilation, and one that may be frequently consulted in cases where the naked-eye stars are suspected of variability. The magnitudes attributed to Ptolemy are not those given in our editions of the "Almagest," but are taken from the work of Sûf ; indeed, Schjellerup considers the former "parfaitement inutiles," being expressed in round numbers and with much confusion, so that in this respect also we have an important addition to our knowledge of the magnitudes of the stars.

In Suff's tables of positions, the longitudes of the Almagest are increased $I 2^{\circ} 42^{\prime}$, the latitudes being unaltered.

Generally spealking, there is a fair agreement between the magnitudes of Ptolemy and Argelander, the differences not often exceeding a degree of the scale. Amongst the larger discorclances Schjellerup points to the cases of 25 Orionis and $\rho$ Eridani, estimated by Ptolemy of the third and fourth magnitudes respectively, while by Argelander they are called a bright fifth and a sixth. Suffi's estimates in the middle of the tenth century are intermediate, the first star being rated a fourth and the second a fifth magnitude. The case of Sirius is worthy of attention for another reason. Cicero, Horace, and other classical writers refer to the ruddy colour of this star. In the editions of Ptolemy it is indicated as vróktopós, but Sûf makes no mention of this reddish tinge, though, as was stated last week, other stars well marked as red stars in our own day, are also so distinguished in his description of the heavens. Instead of reading with Halma ka iтókiṕpos, Schjellerup thinks we should more correctly read kai ofipios, conformable to the designations which Ptolerny gives to the other bright stars which bear a proper name, as with a Bootis (ápкrovpos), a Leonis

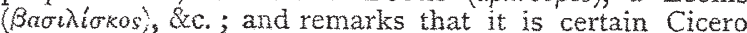
was the first who mentions the ruddiness of Sirius, that Horace followed him, and that after Seneca we find no reference to it. Eratosthenes, Aratus, Manilius, Hyginus, and Germanicus are silent as to this particularity of the star.

The great nebula in Andromeda is named by Súf as an object generally known in the heavens, and it is interesting to note that he also records the variable star recently detected by Herr Julius Schmidt near a Virginis. Its position is very clearly described.

The title of Schjellerup's translation is "Description des Ėtoiles Fixes, composée au milieu du dixième siècle de notre ère, par l'Astronome Persan Abd-al-Rahman alSûfi, par H. C. F. C. Schjellerup, St. Petersbourg, I 874." It was presented to the Imperial Academy in June $1870^{\circ}$

\section{SOLAR RADIATION AND SUN-SPOTS}

GINCEI communicated to NATURE the first results (vol. xii. p. 147) of an examination of the Indian registers of solar-radiation temperatures, I have examined some other registers, all of which confirm the conclusion adumbrated in my former note. Among these the most interesting and striking is the hill station Darjiling, in Sikkim, nearly 7,000 feet above the sea. The place is very cloudy, being on the outer Himalayan range, and much 